\title{
Evaluation of the level of Some Heavy Metals in Tobacco of Domestic and Imported Cigarette Brands Used in Iraq
}

\author{
Majed H. Karbon* \\ Duraid E. Znad**
}

\author{
Faliah H. Ali ** \\ Saad K.Zamil**
}

\author{
Enas J.Hasan* \\ Aamer F.Lafi**
}

*Department of Science /College of Basic Education / University of AL-Mustansiriya/ Iraq

**Department of Materials Research /Ministry of Science and Technology / Iraq

Received 3, June, 2014

Accepted 6, August, 2014

\section{(1) $(9)$}

c. This work is licensed under a Creative Commons Attribution-NonCommercialNoDerivatives 4.0 International Licens

\section{Abstract:}

Smoking-related diseases can be attributed to the inhalation of many different toxins, including heavy metals, which have a host of harmful health effects. The primary objective of this study was to determine whether local and imported cigarette brands used in Iraq, have they elevated levels of metals or not .Three metals Lead $(\mathrm{Pb})$, Cadmium $(\mathrm{Cd})$ and Chromium $(\mathrm{Cr})$ were determined in tobacco of seventeen brands of imported cigarettes commonly available in Iraq and three Iraqi domestic cigarettes, which were randomly taken from retail market in Baghdad by using flame atomic absorption spectrometry.

The produced data of imported and local cigarette brands were discussed and compared together and with studies from elsewhere. The results obtained showed that mean concentrations of lead for all cigarette brands was $5.87 \mu \mathrm{g} / \mathrm{g}$ dry weight (range $2.27-11,67 \mu \mathrm{g} / \mathrm{g}$ ) , cadmium $0.57 \mu \mathrm{g} / \mathrm{g}$ dry weight (range $0.1-1.57 \mu \mathrm{g} / \mathrm{g}$ ) and chromium $3.77 \mu \mathrm{g} / \mathrm{g}$ dry weight (range $0.0-11.21 \mu \mathrm{g} / \mathrm{g}$ ) ..There was a large variability in $\mathrm{Pb}, \mathrm{Cd}$ and $\mathrm{Cr}$ content of samples of cigarettes. $\mathrm{Pb}$ concentration was the highest, followed by $\mathrm{Cr}$ while $\mathrm{Cd}$ was the lowest. The investigation confirmed that most of the Iraqi and imported cigarettes in Iraq are contaminated with $\mathrm{Pb}, \mathrm{Cd}$, and $\mathrm{Cr}$ and quantitatively their distribution is clearly above the safer limits of WHO.

Key words: Cigarette tobacco, Smoking, Toxic Metal, flame atomic absorption spectrometry.

\section{Introduction:}

Cigarettes are smoked worldwide and contain many other substances besides tobacco, filters, and paper. In fact, over 4,000 compounds have been identified in cigarette smoke[1]. cigarette smoke is very harmful and toxic for human health [2]. Some of these toxic materials are heavy metals, particularly cadmium and lead inhaled through. The tobacco plant, Nicotiana tabacum, is known to readily absorb trace elements from the soil and to accumulate them in its leaves at unusually high concentrations. This ability, to accumulate metals, is utilized by modern biotechnology to remove metal contaminations from soil. However, with respect to tobacco farming for cigarette production, this ability of $N$. tabacum becomes a health threatening problem[3].In fact, toxic metals such as Arsenic, cobalt , cadmium, chromium, copper, lead, iron, nickel, manganese and zinc are 
found in different cigarette brands [4,5] .Some of these elements are toxic for humans, even at very low levels of intake. The three of the most prevalent chemicals being cadmium, nickel, and lead. [6,7] .

Cadmium is highly toxic, and is one of the most important heavy metals when the adverse health effects of smoking are considered. Cigarettes may contain from 0.5 to $3.5 \mu \mathrm{g} / \mathrm{g}$ Cadmium [8] .These are very high levels compared with those in food which are normally below $0.05, \mu \mathrm{g} / \mathrm{g}$. The greater part of $\mathrm{Cd}$ in cigarettes (nearly $70 \%$ ) passes into the smoke [9]. Most of the Cd passes into side stream smoke, thus posing a risk to passive smokers.

In human body Cadmium accumulates in kidneys, mainly in the kidney cortex, where metallothioneins chelate $\mathrm{Cd}$ and immobilize it, which may cause tubular dysfunctions and renal end stage failure $[10,11]$. Further, $\mathrm{Cd}$ has been shown to reduce bone mineral density (osteoporosis) and to cause osteomalacia, the combination of which is called itai itai (ouch-ouch) disease .Cd has been linked to the genesis of cancers of the breast, prostate, colon, rectum, kidney and the lung $[12,13]$. Additionally, cigarette smoke delivered $\mathrm{Cd}$ has been shown to reduce birth weight, and although the placenta seems to protect the foetus from maternal $\mathrm{Cd}$, child $\mathrm{Cd}$ burden increases soon after birth via breast milk [14]. Finally, $\mathrm{Cd}$ is under suspicion to cause cataract, emphysema, hypertension, and cardiovascular disease $[15,16,17]$.

Lead plays a significant role in tobacco toxicity. Tobacco contains $\mathrm{Pb}-$ 206 and radioactive $\mathrm{Pb}-210$. Nonradioactive $\mathrm{Pb}-206$ is largely derived from atmospheric pollution. The progenitor of radioactive lead $(\mathrm{Pb}-210)$ is radon 226 which is produced as a natural radioactive decay product from igneous rocks [18]. The use of phosphate fertilizers can increase radon gas levels in areas of low concentration.

After smoking tobacco, $\mathrm{Pb}-210$ and polonium are taken into the lungs. The insolubility of lead may result in small quantities of $\mathrm{Pb}-210$ being retained in the lower bronchial lobes within the lungs, where it causes ongoing radiation damage, potentially increasing the risk of tumors, as it decays into Bismuth-210 and Polonium- 210 [19] .Other possible health consequences of lead accumulation are hypertension and peripheral arterial diseases [20], as well as cataract [15] .

Another heavy metal presents in cigarette smoke is Chromium. It can exist in several oxidation states, although only the trivalent, $\mathrm{Cr}$ (III), and the hexavalent, $\mathrm{Cr}$ (VI), forms are common in the natural environment. It is known that $\mathrm{Cr}$ accumulates in tissue, especially in the lung, its average concentrations in lung tissue were 1.3 $\mu \mathrm{g} / \mathrm{g}$ dry weight in non-smokers and $4.3 \mu \mathrm{g} / \mathrm{g}$ in smokers[21]. It must be born in mind that the biological effects of chromium depend on its valency ; in the trivalent form $\mathrm{Cr}$ is an essential element [22] , in hexavelent form it is carcinogenic .Chromium (VI) compounds, mostly hydroxyl radicals, induce DNA-damage (single strand breaks) [23] and have potential cell transforming effects [24]. Other, non cancerous, effects of $\mathrm{Cr}$ on the respiratory tract include ulceration, chronic rhinitis, impaired lung function and emphysema .

Therefore the monitoring of heavy metals in tobacco is essential for protection of the environment and of our health. This study aimed to determine whether local and imported cigarette brands used in Iraq, have elevated levels of $\mathrm{Pb}, \mathrm{Cd}$ and $\mathrm{Cr}$ heavy metals or not and to compare the 
produced data of cigarette brands both with each other and with the existing brands in different countries.

\section{Materials and Methods:}

Twenty (20) different brands of cigarettes commonly available in Iraq were purchased randomly from local market in Baghdad. These are, Marlboro, Graven"A" , Rothmans, Aspen , Kent , Miami, Afair, Pantly, Gitanes, leader, , Pleasure-light , Davidoff ,Gauloises (Ultra light), Gauloises (Lights) Pine-light , Pine slim , Ghamdan, Ishtar, Sumer (King size) and Sumer (Super king size).

The average weight of each cigarette brand was determined by weighing 5 sticks of each brand. Composites of each brand were prepared by removing the papers and filters of 5 cigarettes selected from a pack of 20. Care was taken to avoid any source of contamination, so that these preparations were carried out in a clean environment. The samples were dried in an oven at a temperature of $85^{\circ} \mathrm{C}$ for $14 \mathrm{~h}$ and allowed to cool in a desiccator. The method of Elinder et al was used [25]. Five grams of tobacco of each cigarette sample was ashed at $500^{\circ} \mathrm{C}$ in a muffle oven. One gram of the ash was treated with concentrated $\mathrm{HNO}_{3}$ and heated to near dryness. The digest was taken up in $1 \mathrm{M} \mathrm{HNO}_{3}$, filtered through No. 4 Whatman filter paper into a $50 \mathrm{ml}$ volumetric flask and made up to volume with deionized water. This was subsequently analyzed for cadmium, lead and chromium using flame atomic absorption spectrophotometer.

\section{Statistics}

Student's $p$ test $(T>t)=0.05$ was used for the statistical analysis of the differences in heavy metals between imported and local cigarettes samples. The statistical evaluation of factors investigated was carried out using the Statistical Package for Social Sciences (SPSS, Version 20).

\section{Results and Discussion:}

The averaged concentrations of heavy metals in Iraqi cigarette brands are presented in (table 1) and (figure 1). The tested Iraqi brands averaged $5.37 \mu \mathrm{g} / \mathrm{g}$ (dry weight) $\mathrm{Pb}$ (range 4.52$6.97 \mu \mathrm{g} / \mathrm{g}$ ), $0.50 \mu \mathrm{g} / \mathrm{g}$ (dry weight) $\mathrm{Cd}$ (range $0.37-0.71 \mu \mathrm{g} / \mathrm{g}$ ) and $2.53 \mu \mathrm{g} / \mathrm{g}$ (dry weight) $\mathrm{Cr}$ (range 0.75-3.56 $\mu \mathrm{g} / \mathrm{g}$ ). According to (table 1), there was no significant difference $(p<0.05)$ in cadmium concentrations between cigarette brands. The lowest concentration was recorded in Sumer (super king size) whereas the highest was in Ishtar. Similarly, no significant difference $(p<0.05)$ was observed in cadmium concentrations among the three cigarette brands. While for chromium there was a significant difference $(\mathrm{p}<0.05)$ among the three Iraqi cigarette brands .The lowest concentration was recorded in Sumer (king size) with $0.75 \mu \mathrm{g} / \mathrm{g}$ whereas the highest value $(3.56 \mu \mathrm{g} / \mathrm{g})$ was in Sumer (super king size) .

Table 1: Concentration $(\mu \mathrm{g} / \mathrm{g})$ of heavy metals in cigarettes manufactured in Iraq.

\begin{tabular}{|c|c|c|c|c|}
\hline \multirow{2}{*}{ NO. } & Cigarette types & \multicolumn{3}{|c|}{ Concentration of heavy metals } \\
\cline { 3 - 5 } & Sumer (blue) king size & Pb Mean $\mu \mathrm{g} / \mathrm{g}$ & $\mathrm{Cd} \mathrm{Mean} \mu \mathrm{g} / \mathrm{g}$ & $\mathrm{Cr} \mathrm{Mean} \mu \mathrm{g} / \mathrm{g}$ \\
\hline 1 & Sumer(black)super king size & 4.643 & 0.374 & 0.753 \\
\hline 2 & Ishtar & 4.528 & 0.428 & 3.557 \\
\hline 3 & Mean \pm SD & 6.968 & $0.50 \pm .18$ & $2.53 \pm 1.55$ \\
\hline & Min. & $5.37 \pm 1.38$ & 0.37 & 0.75 \\
\hline & Max. & 4.52 & 0.71 & 3.56 \\
\hline & WHO Permissible limit & 6.97 & 0.05 & 0.5 \\
\hline
\end{tabular}


The averaged concentrations of heavy metals in imported cigarette brands are presented in (table 2) and (figure 1). It showed a mean $\mathrm{Pb}$ concentration of $5.97 \mu \mathrm{g} / \mathrm{g}$ (dry weight) (range 2.27$11,67 \mu \mathrm{g} / \mathrm{g}$ ). These results were followed by $\mathrm{Cd}$ and $\mathrm{Cr} 0.59 \mu \mathrm{g} / \mathrm{g}$ (range $0.1-1.57 \mu \mathrm{g} / \mathrm{g}$ ) and $3.99 \mu \mathrm{g} / \mathrm{g}$ (range $0.0-11,21 \mu \mathrm{g} / \mathrm{g}$ ) for imported cigarettes, respectively.

On other hand, (table 2) showed that among imported cigarette brands, the highest concentrations of $\mathrm{Pb}$ element were found in Gauloises Lights (11.67 $\mu \mathrm{g} / \mathrm{g})$, Pine -Super slimes $(9.01 \mu \mathrm{g} / \mathrm{g})$ and Pine -Lights $(8.73 \mu \mathrm{g} / \mathrm{g})$ (imported cigarettes) while the highest concentration for $\mathrm{Cd}$ with $1.57 \mu \mathrm{g} / \mathrm{g}$ was found in Rothmans and the highest concentration $\mathrm{Cr}$ with $11.21 \mu \mathrm{g} / \mathrm{g}$ were found in Pine (Lights). The lowest $\mathrm{Pb}$ content was in Davidoff and $\mathrm{Cd}$ content was in Ghamdan cigarettes with 2.269 and $0.102 \mu \mathrm{g} / \mathrm{g}$ respectively. Whereas lowest $\mathrm{Cr}$ content was in Gitanes and Gauloises (Ultra Lights) cigarettes with $0.0 \mu \mathrm{g} / \mathrm{g}$ for both. Therefore, higher concentrations of $\mathrm{Pb}$, $\mathrm{Cd}$, and $\mathrm{Cr}$ were observed in imported cigarette brands as compared to local cigarette brands as shown in (table 3 ).

Table 2. Concentration $(\mu \mathrm{g} / \mathrm{g})$ of heavy metals in imported cigarettes

\begin{tabular}{|c|c|c|c|c|c|}
\hline \multirow{2}{*}{ NO. } & \multirow{2}{*}{ Cigarette types } & \multicolumn{3}{|c|}{ Concentration of heavy metals } & \multirow{2}{*}{ Origin } \\
\hline & & $\begin{array}{c}\mathrm{Pb} \\
\text { Mean } \mu \mathrm{g} / \mathrm{g}\end{array}$ & $\begin{array}{c}\text { Cd } \\
\text { Mean } \mu \mathrm{g} / \mathrm{g}\end{array}$ & $\begin{array}{c}\mathrm{Cr} \\
\text { Mean } \mu \mathrm{g} / \mathrm{g}\end{array}$ & \\
\hline 1 & Gitanes & 6.683 & 0.438 & BDL & France \\
\hline 2 & Graven A & 3.377 & 0.186 & 2.635 & Swiss \\
\hline 3 & Miami & 7.163 & 0.178 & 2.147 & USA \\
\hline 4 & Ghamdan & 3.955 & 0.102 & 3.644 & Oman \\
\hline 5 & Kent & 4.438 & 0.409 & 1.423 & Germany \\
\hline 6 & Gauloises (Ultra Lights) & 5.435 & 1.349 & BDL & France \\
\hline 7 & Pine (Super slimes) & 9.010 & 0.294 & 5.022 & Korea \\
\hline 8 & Davidoff & 2.269 & 1.151 & 1.968 & Germany \\
\hline 9 & Aspen & 2.953 & 0.203 & 3.838 & Germany \\
\hline 10 & Pleasure & 7.274 & 0.432 & 6.015 & Korea \\
\hline 11 & Rothmans & 5.035 & 1.570 & 5.533 & England \\
\hline 12 & Gauloises (Lights) & 11.670 & 0.764 & 5.705 & France \\
\hline 13 & Pine (Lights) & 8.730 & 0.686 & 11.210 & Korea \\
\hline 14 & Marlboro & 6.414 & 1.135 & 5.645 & EU \\
\hline 15 & Affair (Slim) & 6.654 & 0.227 & 3.082 & UAE \\
\hline 16 & Pentley & 6.199 & 0.469 & 7.791 & EU \\
\hline \multirow[t]{5}{*}{17} & Leader & 4.173 & 0.422 & 2.295 & EU \\
\hline & Mean \pm SD & $5.97 \pm 2.42$ & $0.59 \pm 0.45$ & $3.99 \pm 2.86$ & \\
\hline & Min. & 2.27 & 0.10 & 0.00 & \\
\hline & Max. & 11.67 & 1.57 & 11.21 & \\
\hline & WHO Permissible limit & 0.05 & 0.05 & 0.5 & \\
\hline
\end{tabular}

$\mathrm{BDL}=$ Below detection limit

$\mathrm{EU}=$ European Union 


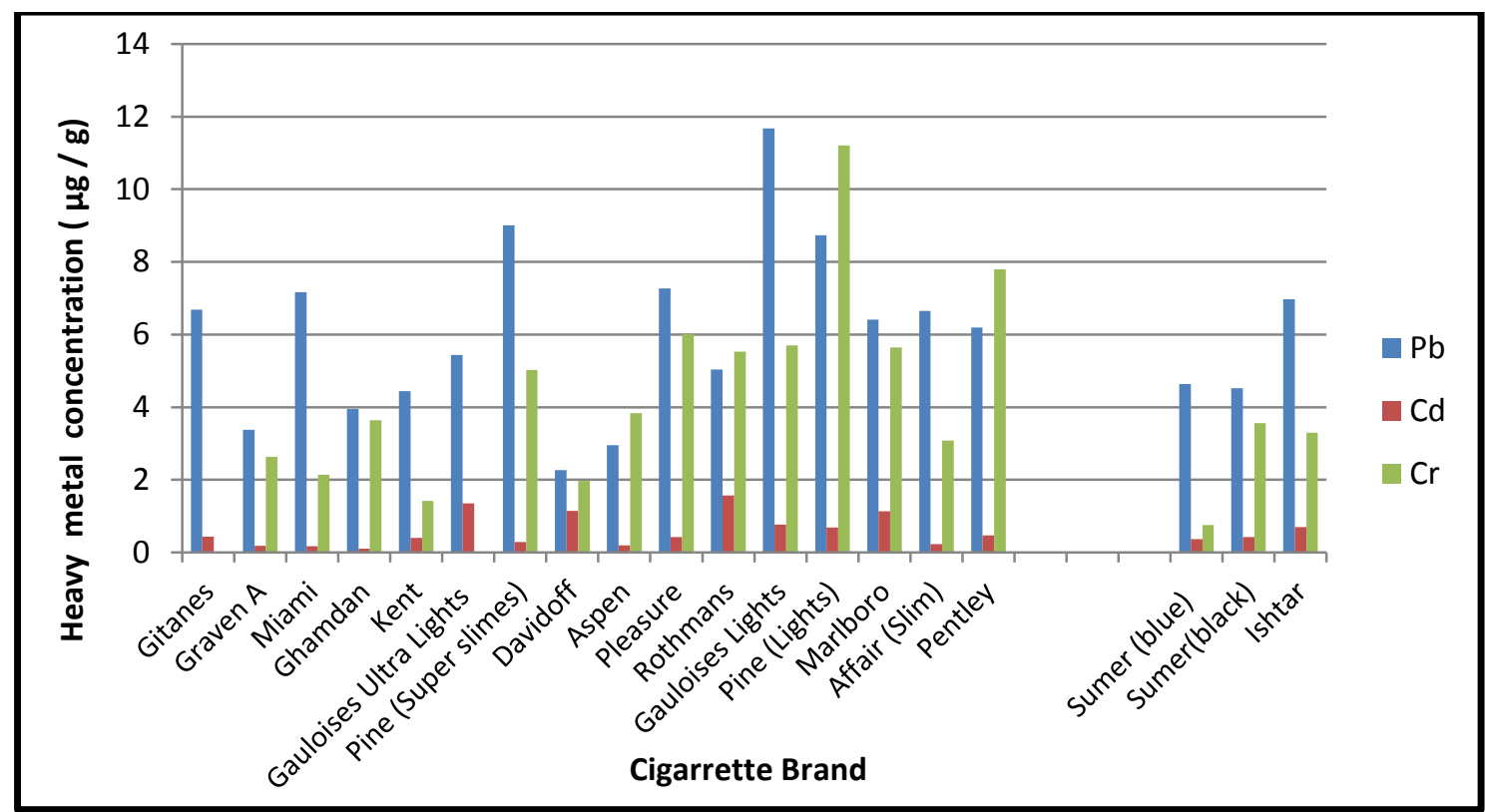

Fig. 1 : Concentration $(\mu \mathrm{g} / \mathrm{g})$ of $\mathrm{Pb}, \mathrm{Cd}$ and $\mathrm{Cr}$ in tobacco of 20 type of Iraqi and imported cigarettes.

Table 3: Comparison of mean concentration of heavy metals contents in Iraqi and imported cigarette brands .

\begin{tabular}{|c|c|c|c|c|}
\hline \multirow{2}{*}{ NO. } & \multirow{2}{*}{ Cigarette types } & \multicolumn{3}{|c|}{ Concentration of heavy metals } \\
\cline { 3 - 5 } & & Pb Mean $\mu \mathrm{g} / \mathrm{g}$ & Cd Mean $\mu \mathrm{g} / \mathrm{g}$ & Cr Mean $\mu \mathrm{g} / \mathrm{g}$ \\
\hline 1 & Iraqi cigarettes & $5.37 \pm 1.38$ & $0.50 \pm 0.18$ & $2.53 \pm 1.55$ \\
\hline 2 & Imported cigarettes & $5.97 \pm 2.42$ & $0.59 \pm 0.45$ & $3.99 \pm 2.86$ \\
\hline & Mean \pm SD & $5.87 \pm 2.27$ & $0.57 \pm .419$ & $3.77 \pm 2.73$ \\
\hline & Min. & 2.27 & 0.10 & 0.00 \\
\hline & Max. & 11.67 & 1.57 & 11.21 \\
\hline
\end{tabular}

Results in (tables 1 and 2) also showed that except for chromium element in Gitanes and Gauloises Ultra Lights cigarettes brands, which contain non-detectable amounts of it, all kinds of Iraqi and imported brands were contaminated with lead $(\mathrm{Pb})$, Cadmium $(\mathrm{Cd})$, chromium $(\mathrm{Cr})$. The levels of metals varied considerably among brands. The amounts reveal that, for all metals, the regulatory limits $(0.05 \mu \mathrm{g}$ $/ \mathrm{g}$ for $\mathrm{Pb}$ and $\mathrm{Cd}$ and $0.5 \mu \mathrm{g} / \mathrm{g}$ for $\mathrm{Cr}$ ) [26] are over passed in most of the brands but the level of contamination varies from one cigarette brand to another one. Such variations in heavy metals concentration of tobacco products have been observed by others as well [27]. However, these variations could possibly be related to agriculture soil and water contents of trace metals on which tobacco leaves were cultivated [28], type of tobacco, growth conditions, and tobacco treatment process[27]. The mean metal contents of cigarettes also varied markedly depending on the geographical area of production [29].

(Table 4) showed that the mean concentration for cadmium in most tobacco was lower than its degree in some tobacco materials sold and/or produced in Jordan $(2.64 \mu \mathrm{g} / \mathrm{g})$, Turkey $(1.1 \mu \mathrm{g} / \mathrm{g})$, Iran $(2.71 \mu \mathrm{g} / \mathrm{g})$, Saudi Arabia $(1.81 \mu \mathrm{g} / \mathrm{g})$, German $(1.95$ $\mu \mathrm{g} / \mathrm{g})$, Korea $(1.02 \mu \mathrm{g} / \mathrm{g})$, Nigeria $(1.43$ $\mu \mathrm{g} / \mathrm{g})$ and USA $(0.86 \mu \mathrm{g} / \mathrm{g})$. 
Table 4. Comparison of the result of studies of heavy metals contents of cigarettes in various countries and results of the present study.

\begin{tabular}{|c|c|c|c|c|}
\hline \multicolumn{3}{|c|}{ Trace metals $\mu \mathrm{g} / \mathrm{g}$} & country & References \\
\hline $\mathrm{Pb}$ & $\mathrm{Cd}$ & $\mathrm{Cr}$ & - & This study \\
\hline 5.87 & 0.58 & 3.77 & Saudi Arabia & {$[33]$} \\
\hline 2.46 & 1.81 & & Jordan & {$[34]$} \\
\hline 2.67 & 2.64 & & Turkey & {$[38]$} \\
\hline 3.7 & 1.1 & 5.0 & Iran & {$[32]$} \\
\hline 2.07 & 2.71 & & Korea & {$[30]$} \\
\hline 1.35 & 1.02 & & German & {$[31]$} \\
\hline 1.2 & 1.95 & & Nigeria & {$[35]$} \\
\hline 1.78 & 1.43 & 1.95 & Philippines & {$[36]$} \\
\hline 1.016 & 0.0037 & $\mathrm{ND}$ & USA & {$[37]$} \\
\hline 0.44 & 0.86 & 2.35 & & \\
\hline
\end{tabular}

$\mathrm{ND}=$ None detectable

(Table 4) also showed that Chromium contents in tobacco brands in Turkey was the highest among all cigarette brands included in this study. In comparison with the reported results for $\mathrm{Pb}$ in tobacco materials sold and/or produced in the Jordan $(2.67 \mu \mathrm{g} / \mathrm{g})$, Saudi Arabia $(2.46 \mu \mathrm{g} / \mathrm{g})$, Turkey (3.7 $\mu \mathrm{g} / \mathrm{g})$, Iran $(2.07 \mu \mathrm{g} / \mathrm{g})$, German (1.2 $\mu \mathrm{g} / \mathrm{g})$, Nigeria $(1.78 \mu \mathrm{g} / \mathrm{g})$, Korean $(1.35 \mu \mathrm{g} / \mathrm{g})$, Philippine $(1.01 \mu \mathrm{g} / \mathrm{g})$ and USA $(0.44 \mu \mathrm{g} / \mathrm{g})$, the average concentration of $\mathrm{Pb}$ element content in all cigarette's tobacco included in this study was the highest among them with $5.87 \mu \mathrm{g} / \mathrm{g}$. As a result we found that tobacco of Iraqi and imported cigarettes used in Iraq have the lowest concentration of $\mathrm{Cd}$ and the highest concentration of $\mathrm{Pb}$.

Because the amount of element absorbed by the body from the smoking process for any type of cigarettes depends on the concentration of element in tobacco[39] so that the high concentrations of toxic elements observed in this study will be harmful to the smokers and passive smokers because when the cigarettes are burned during the process of smoking, metals are retained in the ash with about $70 \%$ transferred to the smoke. The metals, distributed in the mainstream smoke, though present in lower concentrations than inside stream smoke, are responsible for the health anomaly in active smokers while those in the side stream smoke are responsible for some health effect in passive smokers [40].

\section{Conclusion and Recommendations:}

The study has confirmed that most of the Iraqi and imported cigarettes found in Iraq are contaminated with lead $(\mathrm{Pb})$, Cadmium $(\mathrm{Cd})$, chromium $(\mathrm{Cr})$ and quantitatively their distribution is clearly above the safer limits of WHO. Thus, increasing in biological levels of at least these metals which are carcinogenic, represents health risks. So it is fitting that the cigarette manufacturers check the levels of these metals during processing before final packaging, and the legislative arm of the government to enact laws that would control cigarette smoking and subject all cigarettes products to quality control tests to monitor levels of these toxic elements.

\section{References:}

[1] Kleeeman, M. J.; Schauer, J. J. and Cass G.R. 1999.Size and composition of fine particulate matter emitted from wood burning meat charboiling and cigarettes, Environ Sci Technol .33: 35163523.

[2] International Agency for Research on Cancer (IARC) 1986. Tobacco Smoking, IARC Monograph 38, International Agency of Research on Cancer, Lyon, France. 
[3] Bernhard, D.; Rossman A. and Wick G. 2005. Metals in Cigarette Smoke, IUBMB Life .57(12): 805 -809 .

[4] Duran, A.; Tuzen, M. and Soylak, M. 2012 .Trace metal concentrations in cigarette brands commonly available in Turkey: relation with human health, Toxicol Environ Chem 94(10): 1893-1901. doi: 10.1080/ 02772248. 2012. 657200

[5] Lazarević, A.; Nikolić D.; Stošić, L.; Milutinović, S.; Videnović, J. and Bogdanović D. 2012. Determination of Lead and Arsenic in tobacco and cigarettes: An important Issue of public health, Cent Eur J Public Health . 20(1): 62-66.

[6] Menden, R. E.; Elia, V. J.; Michael, L.W.; and Petering, H. C. 1972. Distribution of $\mathrm{Cd}$ and $\mathrm{Ni}$ of tobacco during cigarette smoking, Environ Sci Technol. 6(9): 830-832.

[7] Rhainds, M. and Levallois, P. 1997. Effects of maternal cigarette smoking and alcohol consumption on blood lead levels of newborns, Am J pidemiol. 145(3): 250-257

[8] Mussalo-Rauhamaa H.; Salmela, S. S.; Leppäen, A.; and Pyysalo, H. 1986. Cigarettes as a source of some trace and heavy metals and pesticides in man, Arch Environ Health. 4(1):49-55.

[9] Nandi M., Slone D., Jick H., Shapiro S. and Lewis G.P. 1969. Cadmium content of cigarettes, Lancet. 20(2): 1329-1330.

[10] Jarup, L. 2003. Hazards of heavy metal contamination, Brit Med Bull. 68: 167 - 182.

[11] Satarug, S.; Ujjin, P.; Vanavanitkun, Y.; Nishijo, M.; Baker, J. R. and Moore, M.R. 2004. Effects of cigarette smoking and exposure to cadmium and lead on phenotypic variability of hepatic CYP2A6 and renal function biomarkers in men, Toxicology .204(2-3): 161 173.

[12] Mortada, W. I., Sobh, M. A. and El Defrawy, M. M. 2004. The exposure to cadmium, lead and mercury from smoking and its impact on renal integrity, Med Sci Monit. 10(3): $112-6$.

[13] Satarug, S. and Moore, M. R. 2004. Adverse Health Effects of Chronic Exposure to Low-Level Cadmium in Foodstuffs and Cigarette Smoke, Environ Health Persp. 112(10): 1099 - 1103.

[14] Nishijo, M.; Nakagawa, H.; Honda, R.; Tanebe, K.; Saito, S.; Teranishi, H.; Tawara, K. and Wong, O. 2002. Effects of maternal exposure to cadmium on pregnancy outcome and breast milk, Occup Environ Med. 59(6): 394-397.

[15] Cekic, O. 1998. Effect of cigarette smoking on copper, lead, and cadmium accumulation in human lens, Br J. Ophthalmol. 82(2): 186 -188 .

[16] Hendrick, D. J. 2004. Smoking, cadmium, and emphysema, Thorax 59(3):184-185.

[17] Navas-Acien, A.; Silbergeld, E. K.; Sharrett, R.; Calderon-Aranda, E.; Selvin, E. and Guallar, E. 2005. Metals in urine and peripheral arterial disease, Environ Health Persp. 113(2): 164-169.

[18] Field, R. W. 1999. Radon Occurrence and Health Risks, Occupational and Environmental Medicine Secrets, $1^{\text {st }}$ Ed, Philadelphia, PA, Hanley and Belfus.

[19]Rego, B. 2009. The Polonium Brief- A hidden history of cancer, radiation, and the Tobacco Industry, ISIS. 100(3): 460. 
[20] Navas-Acien, A.; Selvin, E.; Sharrett, A. R.; Calderon-Aranda E.; Silbergeld, E. and Guallar, E. 2004. Lead, cadmium, smoking, and increased risk of peripheral arterial disease, Circulation. 109(25): 3196-3201.

[21] Paakko, P.; Kokkonen, P. and Anttila, S. 1989 .Cadmium and chromium as markers of smoking in human lung tissue, Environ res. 49(2): 197-207.

[22] Mertz W. and Reginsky, E.E. 1987.Chromium metabolism: the glucose tolerance factor. In: Mertz, W. and Cornatzer, W.E., ed. Newer trace elements in nutrition. New York, Dekker, .Ch. 7.

[23] Liu, X.; Lu, J. and Liu, S. 1999 .Synergistic induction of hydroxyl radical-induced DNA single-strand breaks by chromium (VI) compound and cigarette smoke solution, Mutat Res. 440(1): 109117.

[24] Petrilli, F. L.; and De, Flora S. 1982. Interpretations on chromium mutagenicity and carcinogenicity, Prog Clin Biol Res. 109:453-464.

[25] Elinder, C. G.; Kjellstrom, T.; Lind, B.; Linnman, I.; Piscator, M. and Sundstedt K. 1983. Cadmium exposure from smoking cigarette, variations with times and country where purchased, Environ Res. 32(1): 220-227.

[26] Iwuoha, G. N., Oghu, E. I., Onwuachu, U. I. 2013. Levels of selected heavy metals in some brands of Cigarettes marketed in University of Port Harcourt, Rivers State, J Appl Sci Environ Manage. 17 (4): 561-564.

[27] Verma S., Yadav Singh I. 2010. Trace metal concentration in different Indian tobacco products and related health implications, Food Chem Toxicol. 48(8-9): 2291-7.
[28] Stephens, W. E.; Calder, A. and Newton, J. 2005 .Source and health implications of high toxic metal concentrations in illicit Tobacco products, Environ Sci Technol. 39(2): 479-488.

[29] Nnorom, I.C.; Osibanjo, O. and Oji-Nnorom C.G. 2005. Cadmium determination in cigarettes available in Nigeria, African $\mathbf{J}$ Biol. 4:1128-1132.

[30] Jung, M.C.; Thornton I. and Chon H.T. 1998 .Arsenic, cadmium, copper, lead and zinc concentrations in cigarettes produced in Korea and the United Kingdom, Environ Technol. 19(2): 237-241.

[31] Schneider, G. and Krivan, V. 1993. Multi elemental analysis of tobacco and smoke condensate by instrumental neutron activation analysis and atomic absorption spectrometry, Int $\mathrm{J}$ Environ An Ch. 53(2): 87-100.

[32] Alireza, P. and Hamidreza, P. 2012. Investigation of Toxic Metals in the Tobacco of Different Iranian Cigarette Brands and Related Health Issues, Iran J Basic Med Sci. 15(1): 636-644.

[33] Ashraf, M. W. 2012. Concentrations of heavy metals in popular cigarette brands and exposure to these metals via smoking, J Arts, Sci Commer, 2(2): 140-147.

[34] Massadeh, A. M.; Alali, F. Q.; Jaradat, Q. M. 2005. Determination of cadmium and lead in different cigarette brands in Jordan, Environ Monit Assess. 104(1-3): 163-70.

[35] Ishaq, S. E. 2013. Analysis of Heavy Metals in Selected Cigarettes and Tobacco Leaves in Benue State, Nigeria, Ohio J Sci .3(1) 244-247.

[36] Judilynn, S. 2013. Lead, Cadmium and Chromium in Selected Local 
Cigarettes Available in the Philippines, Inte J Chem Envi Engi. 4(4): 205-208.

[37] Caruso, R. V.; O'Connor, R. J.; Stephens, W. E.; Cummings, K. M. and Fong, G. T. 2014. Toxic Metal Concentrations in Cigarettes Obtained from U.S. Smokers in 2009: Results from the International Tobacco Control (ITC) United States Survey Cohort, Int J Environ Res Public Health .11(1): 202-217.

[38] Ali, D.; Mustafa, T. and Mustafa, S. 2012. Trace metal concentrations in cigarette brands commonly available in Turkey: relation with human health, Toxicol Environ Chem. 94(10): 1893-1901.
[39]Al- Omran, L. S. Z. 2008. Determination of Cadmium Content In Domistic And Imported Cigarette In Iraq, Basrh J. Science. 26(1): 55-66.

[40] Yebpella, G. G.; Shallangwa, G. A.; Hammuel, C. B.; Magomya, A.; Oladipo, M. O. A.; Nok, A. N. and Bonire, J. J. 2011. Heavy Metal Content of Different Brands of Cigarettes Commonly Smoked in Nigeria and its Toxicological Implications, Pacific Journal of Science and Technology. 12(1): 356-362.

\section{تقيم مستوى بعض المعادن الثقيلة في تبخ السجائر المحلية والمستوردة

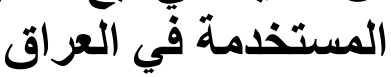
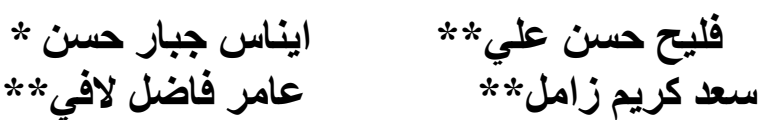

*الجامعة المستتصرية / كلية التربية الأساسية /قسم العلوم

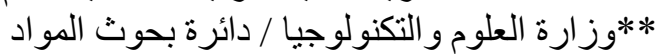

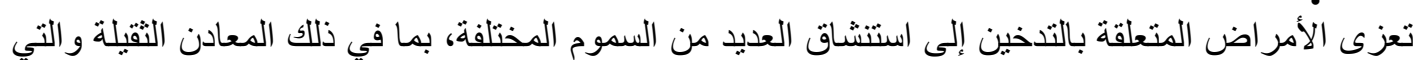

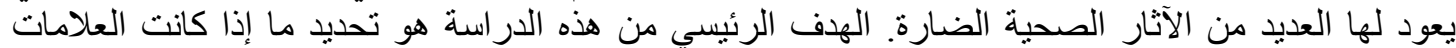

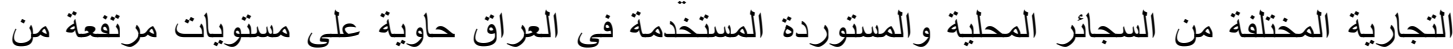

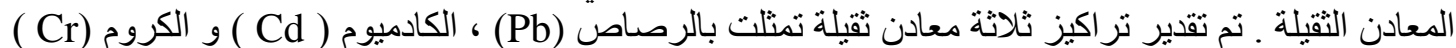

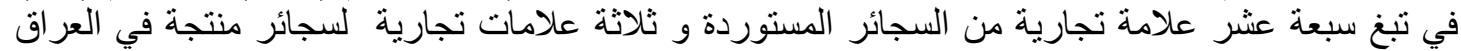

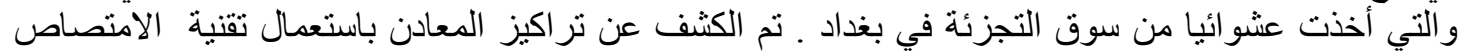

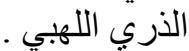

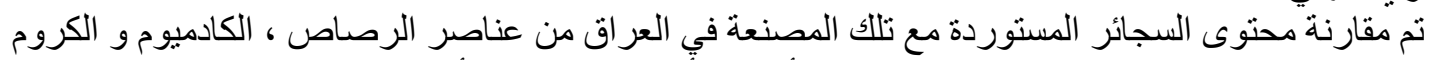

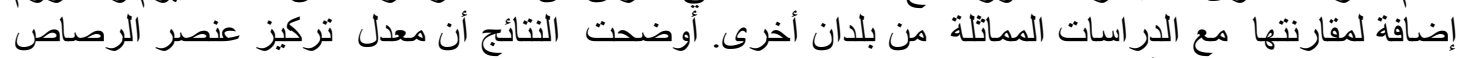

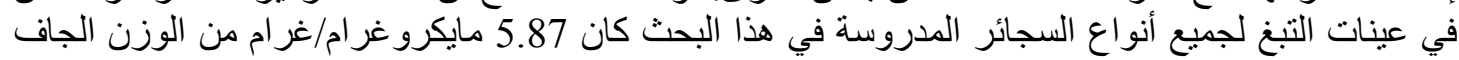

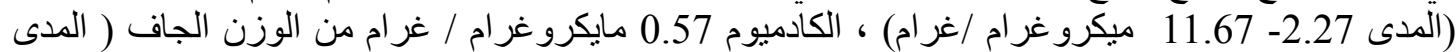

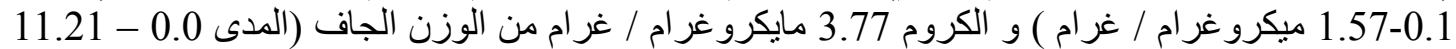

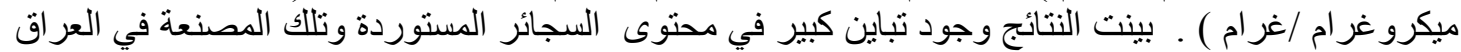

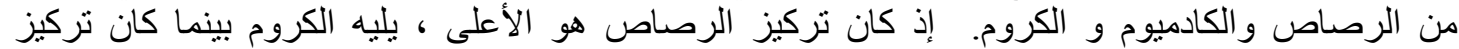

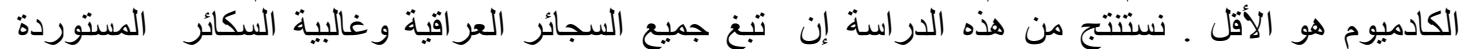

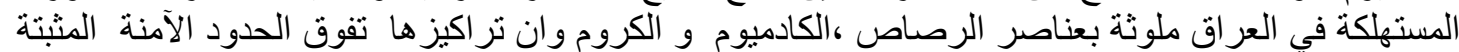

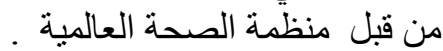
الكلمات المفتاحية : تبغ السكائر، التدخين، المعادن السامة، مطيافية الامتصاص الذري اللهبي. 